\title{
Exploitation of Natural Resources in Kazakhstan: Judicial Practice for Foreign Investment
}

\author{
Bauyrzhan Yessengeldin* \& Zhibek Khussainova** \\ \& Aigul Kurmanova ${ }^{* * *} \&$ Dinara Syzdykova ${ }^{* * * *}$ \\ \& Azamat Zhanseitov ${ }^{* * * *}$
}

Kazakhstan is one of the few countries worldwide endowed with a wealth of diverse natural resources. However, the country has yet to fully exploit these resources, for a variety of reasons, including high levels of corruption, ambiguous laws that cause confusion to the judiciary and consumers. The aim of this paper is to explore the exploitation of natural resource in the country from an international legal perspective. The article demonstrates how corruption hinders the exploitation of natural resources in Kazakhstan. It also describes how the current law seeks to address the issue of natural resource exploitation, noting its ambiguities. The paper concludes by highlighting the provisions made in the UN Declaration concerning Rights to Exploit Natural Resources, and makes recommendations concerning how Kazakhstan's government can promote the rights of citizens to enjoy access to the land and natural resources.

\section{Keywords}

Judiciary, Laws, Natural Resource Exploitation Rights, Kazakhstan

* Dean of the Economics Faculty and Professor of Karaganda State University named after Academician Y.A. Buketov; Editor of Bulletin of the Karaganda University, Economy series. The author may be contacted at: yessen baur@inbox.ru

** Head of the Department of Economics and International Business and Professor of Karaganda State University named after Academician Y.A. Buketov. The author may be contacted at: zhibek_11@mail.ru

*** Associate Professor of the Aktobe Regional State University named after K. Zhubanov. The author may be contacted at:k.aigul_k@mail.ru

**** Senior lecturer of "Accounting and audit" Chair, Karaganda State University named after Academician Y.A. Buketov. The author may be contacted at: nochochek@mail.ru

***** Corresponding author. Lecturer of 'Finance,' Karaganda State University named after Academician Y.A. Buketov. The author may be contacted at: azamat.zhanseitov@icloud.com 


\section{Introduction}

In 1996, Kazakhstan adopted the new constitution, marking the beginning of its journey toward a nation governed by the rule of law. Undoubtedly, the Central Asian country has made remarkable strides towards a democratic and liberal society. One of the areas that Kazakhstan has progressed notably is the improvement of the judicial system. In 2015, the country launched a presidential program that listed 100 concrete steps for improving the investment climate. ${ }^{1}$ The program included 19 measures designed to maintain the supremacy of law. It was envisioned that by implementing these steps, the judiciary would be significantly renovated. The presidential program sought to reduce instances where courts are needed from five to three, and simplify judicial procedures hastening the resolution of disputes, as well as increasing the judiciary's financing and independence. ${ }^{2}$ However, the question of justice has yet to be fully addressed in the program, especially where multiple or foreign parties are involved. For example, adequate time is required to prepare for the hearing, attaining Powers of Attorney and interpreting all the necessary documents. ${ }^{3}$ Therefore, even as the government makes moves to improve the judiciary, it should be careful not to deny access to justice.

Kazakhstan is endowed with a variety of economically valuable natural resources, such as oil, natural gas, uranium, and coal. The petroleum and mining industries contribute 33 percent to the country's GDP and account for over 80 percent of its exports. ${ }^{4}$ Even though Kazakhstan is rich in natural resources, it is not yet fully exploiting them because exploitation rights of (natural resources) are unclear. ${ }^{5}$

This research is to discuss natural resource exploitation rights in Kazakhstan from an international legal perspective. The essay will examine the role of corruption in natural resource exploitation, the level of qualification and ambiguity of laws that might confuse the judiciary and investors, business owners and people who

1 E. Idrissov, Kazakhstan: 100 steps toward a new nation, Diplomat, June 25, 2015, available at https://thediplomat. com/2015/07/kazakhstan-100-steps-toward-a-new-nation (last visited on May 21, 2019).

2 A. Kenjebayeva, Rule of law in Kazakhstan: Maintaining momentum, Zakon.kz, Apr. 29, 2016 available at https:// www.zakon.kz/4790574-rule-of-law-in-kazakhstan-maintaining.html (last visited on May 21, 2019).

3 A. Trochev, Between convictions and reconciliations: Processing criminal cases in Kazakhstan courts, 50 CoRNELL INT'L L. J. 107-45 (2017).

4 M. Karatayev \& M. Clarke, Current energy resources in Kazakhstan and the future potential of renewable: A review, ENERgy Procedia 97-104 (2014).

5 K. Atanesyan, Beating the resource-curse? Lessons from Bolivia, Kazakhstan and Zambia, Independent Evaluation Group, Feb. 1, 2016, available at http://ieg.worldbankgroup.org/blog/beating-resource-curse-lessons-boliviakazakhstan-mongolia-and-zambia (last visited on May 21, 2019). 
are willing to work in the field of natural resources. In this essay, the authors will recommend the most effective ways to promote equity and fairness when determining natural resources exploitation rights.

\section{Corruption and Natural Resources Exploitation}

In Kazakhstan, corruption is the most serious problem for individuals and companies that want to exploit natural resources. Government officials would often ask for bribes to approve the applications for mining licenses in different sectors. ${ }^{6}$ In 2016, Kazakhstan scored 29 out 100 points on the 2016 Transparency International ("TI") Corruption Index. ${ }^{7}$ The level of corruption has remained high in the country for a long time; ranging between 26 and 29 points since $2010 .^{8}$ The corruption would negatively affect the international investment particularly in the mining sector.

In the 2016 TI Corruption Index, mineral rich countries that scored better than Kazakhstan included Canada (82 points), Australia (79 points), Chile (66 points), and South Africa (45 points). ${ }^{9}$ Kazakhstan had identical scores with Russia, but performed better than Democratic Republic of Congo and Zimbabwe, which scored 21 and 22, respectively. ${ }^{10}$ The corruption index is just an example that players in the mining industry face in the country. A critical look at the industry reflects a completely failed legal and judicial system, unable to protect the rights of entities to exploit natural resources, or those of residents to enjoy the right to their own land and national natural resources.

There are two implicit systems that operate in the process of issuing the licenses to miners. The first system is applied to established miners; they appear to have a good relationship with the government without hindrance by corruption, as they engage

6 Kazakhstan's draft mining code likely to make development of major deposits more costly while increasing KazMunayGaz's profile, IHS Markit, June 29, 2017, available at https://ihsmarkit.com/country-industry-forecasting. html?ID=10659122968 (last visited on May 21, 2019).

7 The index ranks countries according to the level of corruption with 0 (zero) indicating 'totally corrupt' and 100 'perfectly clean.' See A. Satubaldina, Kazakhstan removed from list of most corrupt countries, Astana Times, Mar. 1, 2018, available at https://astanatimes.com/2018/03/kazakhstan-removed-from-list-of-most-corrupt-countries (last visited on May 21, 2019).

$8 \quad$ Id.

9 C. Russell, Miners will be lured to Kazakhstan, despite the risks, Reuters, May 29, 2017, available at https://www. reuters.com/article/us-column-russell-mining-kazakhstan/miners-will-be-lured-to-kazakhstan-despite-the-risksidUSKBN18P1PS (last visited on May 21, 2019).

10 Id. 
in their quest to enjoy natural resource exploitation rights. ${ }^{11}$ For example, companies like the Kazzinc, Eurasian, and Polymetal International have been operating in the country for many years, whose senior managers have maintained that their operations are not affected by corruption. ${ }^{12}$

The second system is intended for small players seeking to establish their businesses. Most of them complain about the difficulties they encounter while trying to get approval from government officials. An executive of a small mining company confessed to Reuters that it took over a year to obtain an exploration license, and a further year to use it. ${ }^{13}$ Despite the high corruption levels, a growing number of companies are joining the mining industry. ${ }^{14}$ If the laws dealing with natural exploitation rights were clarified and the regulatory environment improved, however, more companies would be willing to invest in the mining industry. Even taxation can cause problems when investing in natural resources, because the conditions might repel investors in terms of profitability. ${ }^{15}$

\section{Laws regarding Natural Resource Exploitation Rights}

Mining activities in Kazakhstan are basically governed by the Law on Subsoil and Subsoil Use of 2010, which became effective on June 24, 2010. There are other decrees and orders from the ministries of energy and investment and development that address specific issues affecting subsoil use. ${ }^{16}$ One important element of these laws is that any person willing to engage in mining activities should obtain a license through competitive bidding or direct negotiations. The mode of application of a license depends on the status of the applicant and the type of mineral a person hopes to exploit. ${ }^{17}$ For example, government-owned corporations are granted exclusive rights

11 R. Karenov, Y. Orynbassarova, Y. Romanko \& T. Kazbekov, The mining and metallurgical industry of Kazakhstan: Current state of problems and strategic development priorities, 11(7) IEJME - MAтн. Educ. 2239-54 (2016).

12 Id.

13 Russell, supra note 9.

14 Id.

15 B. Yessengeldin et al., Development prospects for problems of the taxation facing subsoil users in the case of Kazakhstan, 39(11) Revista Espacios 33-40 (2017).

16 Kazakhstan's new legal regime for mining, 85-Q2 FTSE Global Markets, June 24, 2018, available at http://www. ftseglobalmarkets.com/issues/issue-85-q2/kazakhstans-new-legal-regime-for-mining.html (last visited on May 21, 2019).

17 A. Kuatbekov, Kazakhstan adopts new subsoil use code, Baker McKenzie, Jan. 24, 2018, available at https://www. bakermckenzie.com/en/insight/publications/2018/01/kazakhstan-adopts (last visited on May 21, 2019). 
to petroleum fields located in selected regions of the country. Similarly, a person who has made a commercial discovery and possesses exploration rights is given priority for a production license, unless $\mathrm{s} /$ he has no capacity to extract the minerals.

A person cannot look for minerals in Kazakhstan without subsoil use rights. The Competent Authority is responsible for granting entities exploration and production rights. The decision of the Competent Authority is informed by the Geology Committee report, which determines the geological allotment of the territory to be explored. ${ }^{18}$ The applicant shall provide the Authority with details of the assessment of commercial discovery which can be used for consideration and approval by the ecological authority. ${ }^{19}$ It is noteworthy that the procedures for applying for the exploration and production of minerals are generally the same for all types of minerals and different types of land.

Miners are required by law to obtain special licenses for activities relating to radioactive ores. The same procedures applicable to other minerals are applied to the exploration and production of natural gas and oil. Article 3.1 of the Subsoil Law provides that foreign entities would have the same rights and carry the same obligations, as those of citizens and legal entities of Kazakhstan with regard to conducting mining activities in the country. ${ }^{20}$ Therefore, everyone has a right to exploit natural resources in Kazakhstan, as long as s/he meet the relevant criteria. In practice, the situation differs on the ground. However, many current and potential investors would be frustrated by the ambiguity of the application of these laws.

\section{Ambiguity of Mining Laws}

In recent, Kazakhstan has changed its mining laws a little to spur growth and attract foreign investments. However, these reforms were not sufficient to provide the industry with the impetus to compete in the international arena. Mining laws are still considered cumbersome by many potential investors. The lawmakers have truly tried to improve subsoil regulations to align them with international mining jurisdictions, but there is still a long way to go. Some of the global mining companies, like BHP Billiton and Vale left the country, refer to the unstable and opaque regulatory

18 Id.

19 Y. Yerkebulanov, Mining laws Kazakhstan 2016, Mondaq, Sept. 16, 2015, available at http://www.mondaq.com/ x/427226/Mining/Mining+Law+Kazakhstan+2016 (last visited on May 21, 2019).

$20 I d$. 
regime. ${ }^{21}$ The Kazakhstan government expects these firms will return once the regulatory environment has improved. It is difficult to establish whether the judicial reforms are currently effective or not, considering none of these large companies who were previously in the country showed an interest in return.

The mining sector is highly prospective, if the government and other relevant parties make reasonable policies and the regulatory setting. One of the major weaknesses of the current law is that the process of obtaining exploitation rights remains complex. The objective of changes in mining law has always been to simplify the procedure of obtaining licenses and other approvals. However, this goal has always tended to be elusive, as potential miners still have to undergo multiple stages to have their applications reviewed and approved. Another issue yet to be resolved by the current mining laws is that of the accessibility of geological data. It is unclear under the current law who should provide investors with information about the geology of the areas in which they want to operate. Nonetheless, the changes significantly reduced the amount of time it takes for investors to gather information from 240 days to one day. ${ }^{22}$ The government now needs to remove the remaining administrative barriers to enhance transparency in the approval process. Then, big and small companies can achieve a level playing field in the industry.

\section{Legal Disputes regarding the Usage of Natural Resources in Kazakhstan}

In many cases, investors would dispute on the accrual of the obligation to pay emissions to the environment, the use of transfer control, and the calculation of rental and corporate income tax. However, they often encounter contentious issues in matters of jurisdiction, because the underdevelopment of legislation governs the resolution of investment disputes. The judicial practice would generally indicate that the courts are currently recovering from so-called 'environmental damage' without the evidence of damage occurrence of based only on the existence of a wrongful act. ${ }^{23}$ The Environmental Code of the Republic of Kazakhstan establishes two methods of

\footnotetext{
K. Koryakovtseva \& L. Novak, Kazakhstan's mining industry, ENGINEERING \& MinING J. 74-92 (2015).

Id.

23 S. Suarez, The right to land and natural resources: In the United Nations Declaration on the rights of peasants and other people working in rural areas, FIAN INT'L BRIEFING 1-8 (2015), available at https://www.fian.org/fileadmin/media/ Publications/Peasants_Rights/PeasantsRights_right_to_land.pdf(last visited on May 23, 2019).
} 
economic assessment of damage to the environment, both direct and indirect. ${ }^{24}$ The position of the courts differs significantly relative to the application of direct and indirect methods of economic assessment of damage. The following approaches are possible:

(1) The correctness of the indirect method is not considered by some courts. We believe that this position of the courts contradicts paragraph 1 of Article 110 of the Environmental Code, which establishes the priority of the direct method of damage assessment;

(2) The damages shall be recovered by applying the indirect method, despite their elimination in nature. We believe that this practice does not comply with paragraph 1 of Article 322 of the Environmental Code, since the person who voluntarily eliminated the damage should not compensate for it in any other way. The Environmental Code does not provide for simultaneous compensation in kind or in value; and

(3) The courts shall deny claims in the application of the direct method on formal grounds. We believe that this position of the courts is facilitated by insufficiently clear legal regulation of the procedure for the compensation of damage (in kind or in value), as defined in Chapters 11 and 46 of the Environmental Code.

According to O.Chentsova and others, ${ }^{25}$ the courts 'shift responsibility' onto the resource user, although the Environmental Code defines that officials from the authorized body (but not nature users) establish economic assessment of the damage caused $^{26}$ and have to consider first the possibility of recovery actions, ${ }^{27}$ irrespective of the availability of the guarantee letter of the resource user.

The authorized bodies, as a rule, do not fulfil this obligation, requiring for the recovery of environmental damage via the indirect method, if the nature user does not apply to the authorized body with a guarantee letter to compensate the damage in kind in accordance with Article 322 of the Environmental Code. Meanwhile, the condition for the application of the indirect method is the impossibility of applying the direct method of economic assessment of damage, which is not taken into account by state bodies and courts in the cases being considered. ${ }^{28}$

24 The Code of the Republic of Kazakhstan from 9 January 2007, No. 212-III «The Environmental Code of the Republic of Kazakhstan» (with changes and addition June 29, 2018), available at https://online.zakon.kz/Document/?doc id $=30085593$ \#pos=2;-250 (last visited on May 21, 2019).

25 O. Chentsova, V. Kim \& L. Emelyanova, Judicial Practice on Ecological Disputes in the Republic of Kazakhstan 3-8 (2013). (Legislation)

26 Environmental Code art. 108, $₫ 2$.

27 Id. art. $109,92$.

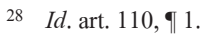


The courts may deny claims where an indirect method of environmental damage assessment has been used, unless a direct method of damage assessment has been applied wherever possible. Such a judicial approach is fully consistent with the law, but these cases are rare. Thus, the priority established by the Environmental Code in terms of the direct method of economic assessment of damage and the restoration of the environment in kind does not work in practice. ${ }^{29}$

Legalization of clearly questionable transactions in court has become a new approach in fraudulent schemes in Kazakhstan. Of course, it is impossible without the participation of some courts and their individual representatives. Thus, the courts are increasingly becoming a 'roof' for various kinds of fraud. With the help of judicial acts, they can deprive the rightful owner of property and allow others to act with impunity to evade all responsibility and damages under the shadow of bankruptcy. ${ }^{30}$

Some combinators implement tricky schemes of profit on companies with solid financial turnover by using the contacts of district and regional courts. Using the links of district and regional courts, some combinators implement schemes of profit on companies with a solid financial turnover. Some of these cases reach the Supreme Court of Kazakhstan, but often its decisions only formally restore the violated rights on paper. It is because the execution of decisions of local courts (recognized subsequently illegal) triggers irreversible processes in the business of debtors and the claimers suddenly as well as unexpectedly declared bankrupt. Therefore, no one could ask for compensation. ${ }^{31}$

According to the Deputy Chairman of the State Revenue Committee of the Ministry of Finance of Kazakhstan M. Takiev, over the past two years, the investment courts received more than 300 claims. $^{32}$ These days, the investment courts consider investment disputes only in Astana court and the Supreme Court. In 2016, the investment courts had 18 civil cases involving state revenue bodies. ${ }^{33}$ The disputed amount reached to 41 billion tenge. At the same time, when considering these disputes in favor of the state revenue bodies, 12 decisions were made out of 18 , by

How to make money "from air" in Kazakhstan courts, TotaL, Aug. 2, 2018, available at https://total.kz/ru/news/ vnutrennyaya_politika/kak_delaut_dengi_iz_vozduha_v_sudah_kazahstana_date_2018_08_02_11_59_24 (last visited on May 21, 2019).

31 Id.

32 D. Serikov, Investors go to the dispute, InBusiness, June 11, 2018, available at https://inbusiness.kz/ru/news/investoryidut-na-spor (last visited on May 21, 2019).

33 Statistical data of economic courts on the parameters of the rating 'Doing Business' on the timing of civil cases for 12 months of 2016, Supreme Court of the Republic of Kazakhstan, Apr. 8, 2018, available at http://sud.gov.kz/rus/ content/statisticheskie-dannye-ekonomicheskih-sudov-po-srokam-rassmotreniya-grazhdanskih-del (last visited on May 21, 2019). 
17.9 billion tenge; three decisions were partially made in favor of the state revenue bodies; and three decisions were made in favor of taxpayers in the amount of 1.3 billion tenge. Here, 93 percent of the disputed amount are in favor of government revenue, while 7 percent are in favor of economic actors. In 2017, the investment courts had 39 civil cases worth 70 billion tenge. This represents a total of 3 percent of all court cases of the state revenue authorities and a total of 30 percent of all cases. In 2017, 32 decisions were made in favor of state revenues, 82 percent, in favor of participants in foreign economic activity: seven cases are worth of 13 billion in total. $^{34}$ There are many questions remain open which require solutions for further development.

\section{International Laws on Natural Resources Exploitation Rights}

As the government strives to improve the regulatory environment for commercial entities, they often forget about the residents of areas where the minerals are situated. At this point, the UN would intervene to ensure the people's rights to enjoy their natural resources that are exploited from their land. ${ }^{35}$ The UN Declaration on the Rights of Peasants and Other People Working in Rural Areas provides that the people working in rural areas have the right to the lands, water bodies, coastal territories, fisheries, pastures, and forests that they occupy. ${ }^{36}$ It declares that the people need these resources to make an acceptable standard of living, and to live in security, peace and dignity, as well as to develop their legal cultures. ${ }^{37}$ The right to land and natural resources extends to a person as an individual and member of community.

The fulfilment of the right to exploit natural resources is considered an important factor in the realization of multiple human rights. The right also carries a number of freedoms and entitlements such as the freedom to maintain existing access to use and manage land and natural resources in a manner that supports them to enjoy the universal right to living a decent life, health, and participation in cultural life. ${ }^{38}$ On the other hand, the entitlements include the right to tenure, use, and management of

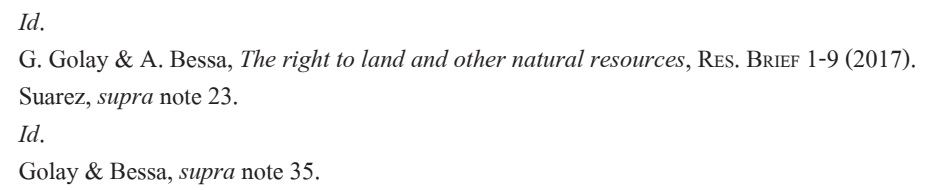


land. ${ }^{39}$ The right to exploit natural resources should be granted in an equitable and sustainable manner without any form of discrimination. The UN Declaration requires the government to ensure that people who have been arbitrarily or unlawfully deprived their right to use their natural resources have been restituted and returned to the lands and natural resources. ${ }^{40}$ If the Kazakhstan government wants to improve the regulatory framework to attract foreign investment into the mining industry, it must consider the impact that the increased activities will have on the people living in areas with these minerals to avoid violating their rights to exploit their lands and natural resources.

The UN Declaration requires states to safeguard the right to land and natural resources. It is the State responsibility to remove the barriers by creating the necessary laws to prohibit any kind of discrimination that relates to the tenure, use, and management systems of land and natural resources. The states are also required to give special attention to groups that have been historically discriminated. ${ }^{41}$ For example, states are supposed to treat groups of women, nomadic pastoralists, Dalits, landless peasants, and workers in a special way to ensure that they are not deprived their right to land and natural resources. States should refrain from doing anything that would prevent people from enjoying the right to land and natural resources. ${ }^{42}$ It is paramount for Kazakhstan to respect the right to land and natural resources of its citizens even as it seeks to exploit different minerals to boost its economy.

\section{Recommendation for Improving Natural Resource Exploitation Rights}

No doubt Kazakhstan's government is facing a mineral resource dilemma even as it tries to improve the regulatory environment to attract domestic and foreign investment in this sector. Most probably, the companies with exploration and mining rights will be operating on land that is already occupied by Kazakhs with the rights to it and the natural resources on them. Subsequently, the government and the mining companies must obtain consent of the local population to exercise the right to exploit the minerals. If the community does not support the decision of the government and

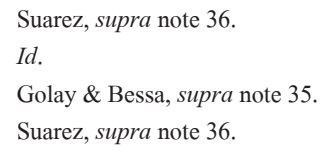


the mining companies, the projects might not even start. ${ }^{43}$ It is imperative to ensure that the local communities are protected in relation to the decision and their rights to land and natural resources.

The primary goal of the mining companies is usually to maximize their commercial profits, which is often achieved at the expense of the local population's right to natural resources. The government is responsible for balancing the needs of the investing firm and its citizens. For example, the government should emphasize to both the investors and local communities the importance of understanding how the mineral resources are geographically distributed and how the investment will promote economic development of the community and the nation at large. The government must also implement laws that will prohibit the businesses from engaging in activities with negative effects on the environment. Therefore, the mineral resource dilemma in Kazakhstan can be resolved by enacting laws that would ensure the demands of local communities in granting companies the rights to exploit natural resources. ${ }^{44}$ The laws should also guide companies on how to address environmental and social issues that might arise during its operations.

\section{Conclusion}

Kazakhstanis endowed with immense mineral and petroleum resources. However, corruption and bureaucracy as well as overbearing judicial system would prevent them from fully exploiting its natural resources. Recent efforts by the government to improve the regulatory framework have not yielded much as global mining companies are yet to return to the country. The Kazakhstan government is still revising the mining laws following international standards in order to attract foreign investment. However, the government must consider the rights of citizens to land and natural resources, even as it grants companies the right to exploit minerals in different parts of the country.

43 N. Nikitina, Mineral resource dilemma: How to balance the interests of government, local communities and abiotic nature, 11 Int'L J. Envtl Res. \& Pub. Health 8632-44 (2014).

44 Id. 